A N N A L ES

UNIVERSITATIS MARIAE CURIE-SKŁODOWSKA

LUBLIN - POLONIA

VOL. LXVI, 2

SECTIO G

2019

Szkoła Wyższa im. Pawła Włodkowica w Płocku

\author{
RAFAŁ KANIA
}

rafalkania@op.pl

ORCID: 0000-0003-2900-6695

\title{
Wojna a myśl polityczno-prawna Królestwa Polskiego w latach 1815-1830
}

War and Polish Political and Legal Thought of the Kingdom of Poland (1815-1830)

\section{WPROWADZENIE}

Krótki okres konstytucyjny Królestwa Polskiego jawi się jako czas spokojny i wolny od zagrożeń, intermedium oddzielające wojny napoleońskie od powstania listopadowego. Przedmiotowe piętnastolecie wydaje się zatem tym okresem dziejów Polski, w którym próżno poszukiwać śladów wojny w świadomości powszechnej. Dalsze rozważania mają na celu weryfikację tej hipotezy. Przedmiotem artykułu jest analiza obecności szeroko rozumianej problematyki wojennej w poglądach reprezentatywnych przedstawicieli polskiej myśli politycznej tego okresu. Obok twórców nadających ton narracji historycznej zostaną zaprezentowane poglądy reprezentantów stronnictwa ugodowego, umiarkowanych realistów, przedstawicieli świata nauki, publicystyki i literatury oraz środowisk radykalnych ${ }^{1}$.

1 Podejmując analizę problematyki wojny w rodzimej myśli politycznej, należy uwzględnić ówczesne znaczenie tego pojęcia, ponieważ początek XIX w. stanowił kluczowy okres dla kształtowania się nowoczesnej siatki pojęciowej myślenia politycznego w języku polskim (zob. F. Pepłowski, Słownictwo i frazeologia polskiej publicystyki okresu Oświecenia i Romantyzmu, Warszawa 1961, s. 5-6). Analiza semantyczna pojęcia prowadzi do wniosku, że nadawano mu sens analogiczny do współczesnego (zob. S.B. Linde, Słownik języka polskiego, t. 6, cz. 1, Lwów 1860, s. 375-376). Jest to uwaga istotna, bowiem w analizowanych tekstach nie ma definicji wojny, ale można odnotować wątpliwości wokół znaczenia przedmiotowego pojęcia. 


\section{POLSKA I WOJNY NAPOLEOŃSKIE W ŚWIETLE ANALIZ WSPÓŁCZESNYCH KOMENTATORÓW}

Problematyka wojenna została mocno wyeksponowana w poglądach myślicieli wykazujących predylekcje do formułowania uogólnień historycznych. Osią dalszych rozważań będą poglądy ugodowca Fryderyka Skarbka, reprezentanta środowisk liberalno-konserwatywnych Stanisława Barzykowskiego oraz przedstawiciela nurtu radykalno-niepodległościowego Maurycego Mochnackiego. Zabieg ten pozwoli nakreślić kontekst historyczny dla rozważań innych myślicieli, a także naszkicować horyzonty ówczesnej debaty poświęconej wojnie.

W opinii umiarkowanego Barzykowskiego rewolucja francuska oraz upadek Rzeczypospolitej stanowiły dwa wydarzenia o kluczowym znaczeniu dla dziejów Europy początku XIX w. ${ }^{2}$, przy czym sprawa polska była na arenie międzynarodowej traktowana instrumentalnie. Czynili tak Napoleon i Aleksander $\mathrm{I}^{3}$. Przechodząc do oceny polityki cara wobec Polaków podczas kampanii 1812 r., Barzykowski podkreślił szczególny wpływ działań ks. Adama Jerzego Czartoryskiego. Zdaniem autora był to sprzyjający moment do odtworzenia Polski w powiązaniu z Rosją. Car nie wykorzystał jednak dogodnej okazji, z czego zdał sobie sprawę, obserwując gremialne opowiedzenie się Polaków po stronie francuskiej. ${ }^{4}$ Nie umknął uwadze Aleksandra I także fakt, iż wojsko Księstwa Warszawskiego mówiło o sobie jako o wojsku polskim ${ }^{5}$.

Sytuacja zmieniła się wraz z intensyfikacją przygotowań wojennych. Zdając sobie sprawę ze znaczenia Polaków dla przebiegu konfliktu, Napoleon i Aleksander I prześcigali się w obietnicach. Były to zabiegi o charakterze taktycznym. Miały one skłonić Polaków do opowiedzenia się po jednej ze stron. Zdaniem Barzykowskiego sytuacja ta potwierdzała prawidłowość, podług której zawsze, kiedy dochodziło do konfliktu między Zachodem i Rosją, sprawa polska stawała się kartą przetargową ${ }^{6}$.

Wraz z upadkiem Napoleona rozpadł się tworzony przez niego porządek polityczny w Europie budowany na bagnetach francuskiej armii. „Po ostatniej wojnie, po ostatniej koalicji przeciw Napoleonowi, temu ukoronowanemu plebejuszowi, temu zbrojnemu reprezentantowi nowego świata, mocarze Europy zwycięzcami zostało, spełnili restaurację dawnego porządku rzeczy i zdało im się, że rewolucja zniszczona, duch rewolucyjny poniżony i restauracja panować będzie"’

Klęska Napoleona rozwiała nadzieje na niepodległość Polski dzięki Francji. Spekulowano jednak, że będzie on próbował wrócić do wielkiej polityki. Alek-

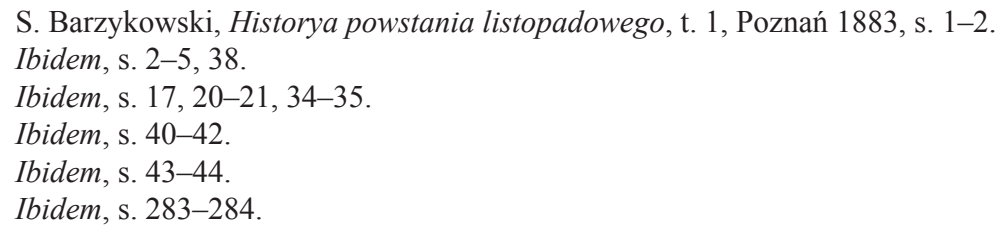


sander I miał nadzieję, że Polacy poznali już intencje cesarza ${ }^{8}$. Ostatecznie dominująca pozycja Rosji w koalicji antynapoleońskiej spowodowała, że car zyskał decydujące zdanie w kwestii polskiej. Dlatego nikt nie protestował, kiedy w Paryżu objął kuratelą resztki polskiego wojska, powołał do życia komitet wojskowy i postawił na jego czele swojego brata9.

Rzeczywiste intencje cara w kwestii polskiej ujawniły, w opinii Barzykowskiego, decyzje personalne. Nominacja gen. Zajączka na stanowisko namiestnika, przydzielenie Konstantemu Pawłowiczowi dowództwa nad armią oraz udzielenie szczególnych pełnomocnictw Mikołajowi Nowosilcowowi wyraźnie wskazywały na instrumentalne traktowanie Polaków podczas realizacji długofalowej strategii politycznej ${ }^{10}$. Julian Ursyn Niemcewicz ${ }^{11}$ oraz Joachim Lelewe ${ }^{12} \mathrm{w}$ rozważaniach poświęconych kształtowaniu porządku europejskiego podczas kongresu wiedeńskiego doszli do wniosku, że zawłaszczenie armii Królestwa Polskiego przez carewicza wpisywało się w doktrynę obronną Rosji polegającą na budowie systemu państw buforowych na zachodniej flance Imperium.

Mocarstwa zachodnie kreowały własną wizję korzyści wynikających z utworzenia Królestwa Polskiego. Ich stanowisko wobec sprawy polskiej Barzykowski interpretował jako oczekiwanie na realizację obietnic Aleksandra I w kwestii odtworzenia Rzeczypospolitej. Polska stałaby się wtedy buforem chroniącym Europę przed ekspansją rosyjską. Według alternatywnego scenariusza ziemie polskie mogły zostać włączone w skład Imperium Rosyjskiego, co spowodowałoby nienawiść Polaków, która w przypadku wojny kazałaby opowiedzieć się im przeciw Rosji. Nie kwestionowano jednak pozostawania ziem polskich w strefie wpływów rosyjskich. Mogła mieć na to wpływ argumentacja Aleksandra I, który twierdził, że Polacy są gotowi opowiedzieć się po jego stronie w przypadku konfliktu dotyczącego rozwiązania sprawy polskiej ${ }^{13}$.

Barzykowski wspominał rozczarowanie znacznej części Polaków decyzją kongresu wiedeńskiego o utworzeniu niewielkiego Królestwa Polskiego. „Niekiedy nazywano ją zabytkiem napoleońskim, nawet partią francuską" ${ }^{14}$. W tej grupie należało doszukiwać się pierwszych zalążków konspiracji niepodległościowej. Chociaż Polacy zaprzestali walki zbrojnej, nie zapomnieli o niepodległości. Tej postawy nie rozumieli Rosjanie chcący traktować Królestwo Polskie jako zdobycz wojenną, o czym świadczyły liczne nadużycia władzy ${ }^{15}$. Ten stan rzeczy rodził napięcie prowadzące do otwartego konfliktu.

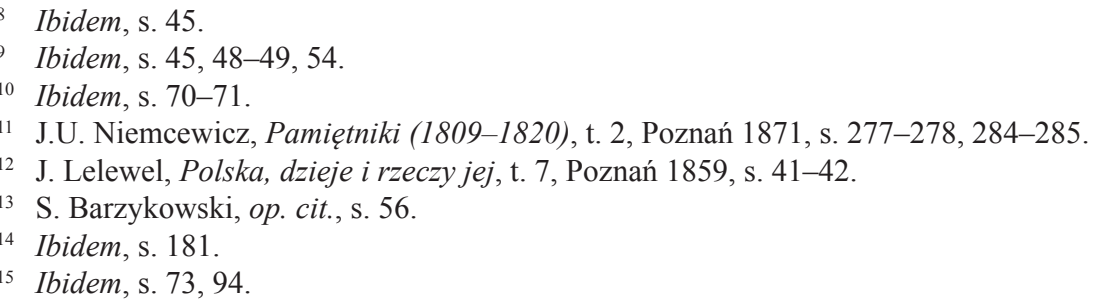


Reprezentujący radykalne środowisko niepodległościowe Mochnacki oceniał skutki polityczne wojen napoleońskich bardzo krytycznie. Uważał, że istnienie caratu opierało się na dwóch założeniach: przemocy oraz czynniku uaktywniającym agresywną siłę. Byt polityczny, jakim była Rosja, nie obejmował narodu i społeczeństwa. Był jedynie państwem, narzędziem w ręku carów. Ów twór dysponował siłą ekspansywną niespotykaną od czasów Imperium Rzymskiego. Jego potęga wynikała wyłącznie ze zdobyczy. Gdyby Napoleon dostrzegł tę prawidłowość, zrozumiałby również szczególną rolę Polski jako czynnika kluczowego dla uzyskania równowagi politycznej w tej części Europy, buforu oddzielającego Zachód od agresywnej Rosji ${ }^{16}$.

Utworzenie Królestwa Polskiego w 1815 r. stanowiło efekt wojen napoleońskich, zwycięstwa koalicji antynapoleońskiej oraz próby utworzenia stabilnego ładu europejskiego. Zdaniem Mochnackiego droga do niepodległości Polski wiodła wyłącznie przez konflikt zbrojny między zwycięzcami. Było do niego blisko, jednak powrót Napoleona z Elby zmusił negocjujących władców do kompromisu. Aleksander I celowo stwarzał wrażenie, że Polacy są gotowi walczyć u jego boku o niepodległość, skutkiem czego większość ziem polskich przypadła Rosji ${ }^{17}$.

Mochnacki uważał, że dominacja polityczna i militarna Rosji w Europie stała się możliwa wyłącznie kosztem Polski. W przeszłości efekty tego stanu rzeczy odczuła jako pierwsza Turcja. Utworzenie Królestwa Polskiego umożliwiło rozszerzenie kontroli na środkową część kontynentu, głównie Austrię i Prusy ${ }^{18}$. „Sekret moskiewskiej potęgi tkwi w Polszcze: stąd car jedną ręką sięga do Stambułu, drugą do Paryża; stąd wpływa na Wschód i na Zachód"19.

Analizując sytuację w Europie, myśliciel nie ograniczał się wyłącznie do rozpatrywania jej aspektów militarnych i politycznych. Pośród konsekwencji wojen napoleońskich (w szczególności ekspansji Napoleona na wschód oraz dotarcia Aleksandra I do Paryża) wskazywał także na przemiany cywilizacyjne. Wojny doprowadziły do pojawienia się szeroko w świadomości ludzkiej nowych idei i prądów umysłowych. Miały one istotny wpływ na „oświecenie” znacznej części mieszkańców Rosji ${ }^{20}$.

Opracowując syntezę dziejów polskich, Skarbek dokonał analizy procesów historycznych w dłuższym horyzoncie czasowym. Zauważył, że od momentu, gdy carat wkroczył na arenę polityczną Europy, Polska - oddzielająca Imperium od reszty kontynentu - nie mogła pozostać niepodległym bytem politycznym.

16 M. Mochnacki, Powstanie narodu polskiego w roku 1830 i 1831, t. 1, Warszawa 1984, s. $73,78-79,140,143$.

17 Ibidem, s. 125, 135.

18 Ibidem, s. 61.

19 Ibidem, s. 131.

20 Ibidem, s. 266. 
W doktrynę budowy rosyjskiej potęgi i ekspansji wpisywało się też stopniowe zagarnianie ziem polskich ${ }^{21}$.

Utworzenie Księstwa Warszawskiego spowodowało odrodzenie ducha narodowego. Był to jednak niesamodzielny byt polityczny. Skarbek zauważył, że większość Polaków poddała się woli Napoleona niezależnie od oceny korzystności jego działań dla interesów narodowych. Upadek cesarza pokazał, do czego prowadzi bezgraniczne zaufanie w polityce. Wojny tego okresu udowodniły jednak, że Polacy stanowili istotny element gry politycznej w Europie ${ }^{22}$.

Dostrzegał ten fakt car, który podczas kampanii 1812 r. sugerował gotowość do odbudowy niepodległej Polski. W opinii Skarbka tę deklarację należało traktować jako element taktyki politycznej wynikającej z trudnego położenia Rosji w obliczu wojny z Francją ${ }^{23}$. Sytuacja zmieniła się podczas obrad kongresu wiedeńskiego. Aleksander I zażądał Księstwa Warszawskiego jako rekompensaty za szczególny wkład Rosji w pokonanie Napoleona. Car zagroził, że woli kolejną wojnę z dotychczasowymi koalicjantami, aniżeli ustąpić z zajętych zdobyczy terytorialnych. Spór groził kolejnym konfliktem, lecz ostatecznie powrót Napoleona skłonił strony do kompromisu ${ }^{24}$.

Dokonując porównania wniosków odnośnie do ówczesnej sytuacji politycznej, wydaje się, że spośród komentatorów rzeczywiste intencje Aleksandra I względem Polaków najlepiej odczytał Skarbek. Zauważył, że wkraczając zbrojnie do Księstwa Warszawskiego, car miał wszelkie instrumenty do tego, aby ujarzmić siłą naród występujący po stronie największego wroga Rosji. W swojej polityce długofalowej dążył jednak do opanowania całych ziem dawnej Rzeczypospolitej. To był podstawowy powód niewcielenia ziem polskich do Imperium. Zamiast ryzykować kolejny konflikt zbrojny, wolał doprowadzić do zmiany nastawienia Polaków poprzez stosowanie działań miękkich. Chciał ustępstwami oraz zapowiedziami korzystnych posunięć politycznych zmienić Polaków w spolegliwych poddanych. Królestwo Polskie nie było zatem ani wynikiem obłudnej gry carskiej, ani przejawem jego szczególnej wspaniałomyślności wobec Polaków. Stanowiło efekt długofalowej strategii politycznej Aleksandra I, zmierzającego do naprawienia błędu Katarzyny II i samodzielnego opanowania ziem polskich z pominięciem Prus i Austrii ${ }^{25}$.

Lata 1815-1830 były zdaniem Skarbka okresem „burzliwej młodości”, nadmiernej swobody niekorzystnie wpływającej na życie polityczne kraju i prowadzącej do nierozważnego kroku - zbrojnego powstania. Sytuację porównał do sta-

${ }^{21}$ F. Skarbek, Dzieje Polski, cz. 2: Królestwo Polskie od epoki początku swego do Rewolucyi Listopadowej, Poznań 1877, s. 1.

22 Ibidem, s. XII-XIII.

23 Ibidem, s. 5.

24 Ibidem, s. 15-16, 30.

25 Ibidem, s. 44-45. 
nu człowieka wyglądającego pozornie na zdrowego, który ma niezdiagnozowaną śmiertelną wadę serca. Polacy stali się ludźmi czynu, dźwigającymi niecierpliwie jarzmo niewoli, gotowymi w każdej chwili do podjęcia walki ${ }^{26}$. Wspólne doświadczenia powinny doprowadzić Rosjan i Polaków do konstruktywnych wniosków: pierwszych, że przemocą nie można pokonać ducha narodowego Polaków, natomiast drudzy powinni zrozumieć, iż nie są w stanie prowadzić skutecznej walki zbrojnej z Imperium Rosyjskim, w szczególności wobec solidarności między zaborcami ${ }^{27}$.

\section{WOJNA A STANOWISKO POLITYCZNE REPREZENTANTÓW ŚRODOWISKA UGODOWEGO}

W przekonaniu elit politycznych utworzenie Królestwa Polskiego stanowiło wyłącznie efekt wspaniałomyślności Aleksandra I. Podczas uroczystości inaugurujących obrady Sejmu w 1818 r. senator Józef Wybicki podkreślił dobrodziejstwa cara. Zauważył, że na przekór zwyczajom wojennym, według których zwycięzcy traktują pokonanych bezwzględnie, Aleksander I nie tylko powstrzymał się od tego rodzaju działań, ale także nadał Królestwu Polskiemu konstytucję, a Polakom dał wolność osobistą ${ }^{28}$. Wybickiemu wtórował prezes Senatu Stanisław Kostka Potocki, wyrażający wdzięczność za odbudowę państwowości polskiej. Podkreślił dobroć cara, mimo że „od dawna los [...] przeciwny, zapisywał go [naród polski - R.K.] w liczbę nieprzyjaciół”29 Aleksandra I. Przemówienie cara podczas inauguracji Sejmu 1818 r. utwierdziło zebranych w przekonaniu o jego dobrych intencjach wobec Polaków ${ }^{30}$.

Wpływ na stanowisko polskich elit politycznych wobec cara miały nieodległe wydarzenia wojenne. W raporcie o stanie Królestwa Polskiego zaprezentowanym podczas Sejmu 1818 r. minister spraw wewnętrznych i policji Tadeusz Mostowski wskazał na karność wojsk rosyjskich podczas ich pobytu na terytorium Księstwa Warszawskiego, pomimo zajęcia wrogiego państwa. Z raportu wyłaniał się również katastrofalny stan państwa spowodowany wyniszczającymi działaniami wojennymi ${ }^{31}$.

$\mathrm{Na}$ atmosferę panującą w środowisku elit rządowych Królestwa Polskiego oddziaływała postawa namiestnika Zajączka, zaawansowanego wiekiem inwalidy, który „był zawsze potulny, posłuszny i gotów dosługiwać na innem niż do-

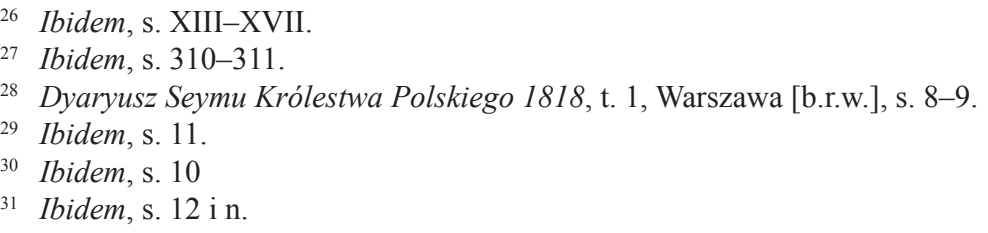


tychczas polu" ${ }^{\prime 32}$. Od momentu dostania się do niewoli pod Berezyną eksjakobin i weteran wojsk napoleońskich grawitował ku caratowi. Zajączek zawsze gotów był opowiedzieć się po stronie zwycięzcy. Dlatego tak jak wcześniej wiernie służył Napoleonowi, tak z czasem zaczął być oddany Aleksandrowi I. Barzykowski przytoczył wypowiedź namiestnika: „Nie Polsce, lecz cesarzowi Aleksandrowi wszystko winienem, czem jestem z jego łaski, przeto przede wszystkim wierny jemu będę i co on każe, wszystko spełnię" ${ }^{\prime 33}$. Na podobne wypowiedzi namiestnika wskazywał także Julian Ursyn Niemcewicz ${ }^{34}$. Z kolei Kajetan Koźmian uważał, iż wybór Zajączka na namiestnika, aczkolwiek był dla Polaków niemiłym zaskoczeniem, z punktu widzenia polityki Aleksandra I należało uznać za rozsądny. Chodziło wszak o wybór Polaka oddanego carowi. Zajączek spełniał te oczekiwania $^{35}$.

Oceniając postawę ugodowców wobec sytuacji wewnętrznej Królestwa Polskiego, Mochnacki zwracał uwagę na upokorzenia, jakich doznawali żołnierze ze strony wielkiego księcia Konstantego. Jego despotyzmu nie uniknęli nawet zasłużeni weterani. Mimo to wielu spośród nich wykazało się skrajnym serwilizmem, wykraczającym poza wojskową karność. Pośród oficerów bezgranicznie oddanych caratowi wymienił generałów: Zajączka, Kurnatowskiego, Hauke, Trębińskiego i Potockiego. Nie byli to ludzie z gruntu źli, ale stali się takimi w wyniku uległości wobec carewicza ${ }^{36}$. Mochnacki szczególnie podkreślił skrajny serwilizm i bezwzględność gen. Hauke, prezesa nadzwyczajnego sądu wojennego rozstrzygającego sprawę Łukasińskiego ${ }^{37}$. Podzielił ten pogląd Barzykowski, przytaczając z kolei jego opinię na temat wyroku Sądu Sejmowego ${ }^{38}$.

Dla identyfikacji atmosfery panującej wśród ugodowców znamienne są również przytoczone przez Mochnackiego słowa uznawanego za bohatera i patriotę gen. Chłopickiego. Kiedy próbowano przekazać mu władzę tuż po wybuchu powstania, miał stwierdzić: „Moją ojczyzną - jest namiot! Wasza ojczyzna nie sprawiłaby mi i butów" ${ }^{39}$. Słowa te świadczą o stosunku generała do wojny z Rosją. Warto w tym miejscu postawić pytanie: Skoro takie przekonanie żywił potencjalny wódz tuż po rozpoczęciu walki, to jakie nastroje musiały panować wśród serwilistów?

Równie ugodową wobec caratu postawę, aczkolwiek wynikającą z odmiennych przesłanek, bo opartych na pogłębionej refleksji filozoficznej, zajął Józef Kalasanty Szaniawski. Predylekcje filozoficzne nakazywały temu przedstawicie-

\footnotetext{
32 S. Barzykowski, op. cit., s. 98.

3 Ibidem, s. 101.

J.U. Niemcewicz, op. cit., s. 273-274.

K. Koźmian, Pamiętniki, t. 3, Wrocław 1972, s. 113.

M. Mochnacki, Powstanie..., s. 169.

Ibidem, s. 258-259.

8 S. Barzykowski, op. cit., s. 166.

39 M. Mochnacki, Powstanie ..., s. 331.
} 
lowi kantyzmu poszukiwać głębszego uzasadnienia dla podejmowanych wyborów. Chociaż część refleksji politycznej powstała przed utworzeniem Królestwa Polskiego, w praktyce miała ona możliwość pełnego zaistnienia po upadku Napoleona. Poglądy myśliciela zaważyły na stanowisku podczas prac nad projektem konstytucji Królestwa Polskiego, w tym na rozstrzygnięciach dotyczących obronności państwa. Według Szaniawskiego właściwe określenie w ustawie zasadniczej zasad organizacji stałej armii oraz źródeł jej finansowania powoduje ustanie zagrożenia buntami nieopłaconego wojska oraz eliminuje niebezpieczne zjawisko utrzymywania prywatnych armii, grożące wojnami domowymi ${ }^{40}$.

Wojskowość, rozumował Szaniawski, przeszła długi proces doskonalenia. W przeszłości umiejętności te służyły częściej ambicjom zdobywców i tylko niekiedy przynosiły pośrednią korzyść ludzkości. Pozytywne efekty doskonalenia sztuki wojennej uważał za trudne do zidentyfikowania. Z pewnością jednak pozwalały powrócić naturze człowieka do pierwotnej czerstwości oraz powstrzymywały pęd wątlejącej ludzkości ku zniewieścieniu. Męstwo związane z wojną wpływało pozytywnie na społeczeństwo oraz wywoływało osobistą satysfakcję w wyniku poświęcenia na rzecz ojczyzny. „Wtedy nie część jedna, ale narodowa całość, rozwijać by na sobie zaczęła w wielkiej szkole męstwa to tak istotne ludzkości znamię..."41.

Pośród osób odgrywających istotną rolę w okresie dojrzewania wizji Królestwa Polskiego znalazł się Michał Kleofas Ogiński. Pogląd na temat wojen napoleońskich oraz rywalizacji przedstawicieli orientacji profrancuskiej i prorosyjskiej zawarł we wspomnieniach spisanych pod koniec życia we Florencji. Polityk ten kwestionował pogląd o gotowości Napoleona podczas wojny 1812 r. do odbudowy niepodległej Polski, a już z całą pewnością chęć odtworzenia jej tak potężnej, jak przed rozbiorami. Nie było to możliwe, nawet gdyby cesarz zwyciężył w wojnie z Rosją. Z kolei w przypadku prawdopodobnej jego klęski, jak rzekomo przewidywał przed 1812 r. autor wspomnień, Polacy występujący przeciwko carowi musieli liczyć się z utrwaleniem niewoli. Dlatego uważał, iż rozsądniejszym ówcześnie posunięciem było opowiedzenie się po stronie Aleksandra ${ }^{42}$.

Ogiński zarzucał Polakom naiwność i megalomanię. Oczekiwania, iż zwycięski Aleksander I dobrowolnie ustąpi z zajętych terytoriów polskich, aby odtworzyć niepodległą Polskę, uznawał za niedorzeczność. Niezależnie od osobistego stosunku do Polaków car miał bowiem na uwadze interes Imperium Rosyjskiego, a nie realizowanie polskich mrzonek. Dlatego jego gesty względem Polaków

40 J.K. Szaniawski, Ogólniejsze myśli względem projektowania [Konstytucji Królestwa Polskiego], [w:] Kręte drogi myśli politycznej Józefa Kalasantego Szaniawskiego (1764-1843), oprac. S. Paczos, Poznań 2012, s. 492.

${ }^{41}$ Idem, Noty do „, O naturze i przeznaczeniu urzędowań w społeczności”, [w:] Kręte drogi..., s. $289-290$.

42 M.K. Ogiński, Pamiętniki Michała Ogińskiego o Polsce i Polakach od r. 1788 aż do końca r. 1815, t. 3, Poznań 1870, s. VIII-IX. 
oceniał wyłącznie jako narzędzie służące do uzyskania ich przychylności. To był główny cel polityki carskiej wobec narodu służącego Napoleonowi ${ }^{43}$.

Złożone stanowisko wobec Rosji zajmowała jedna z głównych postaci życia politycznego i społeczno-gospodarczego Królestwa Polskiego - ks. Franciszek Ksawery Drucki-Lubecki. Minister skarbu był niewątpliwie nastawiony ugodowo, chociaż nie spolegliwie, wobec caratu. Jego horyzonty polityczne nie sięgały poza koncepcje rozwoju kraju w ścisłym związku z Rosją. Z drugiej strony konsekwentnie budował silną pozycję gospodarczą państwa, która miała zagwarantować maksimum niezależności w relacjach z silniejszym partnerem. Kreśloną wizję plastycznie oddaje jego wypowiedź przytoczona przez Ludwika Platera. Podczas jednej z rozmów ks. Drucki-Lubecki miał stwierdzić:

Polsce trzech rzeczy trzeba [...] 1) szkół, tj. oświaty i rozumu, 2) przemysłu i handlu, tj. zamożności i bogactwa, 3) fabryk broni; to posiadając, nawet i w połączeniu z Rosją, potrafi całkowicie swą niepodległość utrzymać [...]. Polska powinna mieć wszystko, czego potrzeba do zagwarantowania niepodległości, inaczej wszystko straci ${ }^{44}$.

Jeżeli wypowiedź ta rzeczywiście padła z ust ministra, to świadczy ona nie tylko o pragmatyzmie, ale również o szczególnego rodzaju patriotyzmie nakazującym budowę silnego państwa w bardzo ograniczonej przestrzeni politycznej.

\section{OCENA WOJNY I JEJ SKUTKÓW Z PERSPEKTYWY MYŚLICIELI UMIARKOWANYCH}

$\mathrm{Z}$ racji odegranej roli w bieżących wydarzeniach oraz zajmowanej pozycji politycznej na pierwszym planie wśród polityków umiarkowanych należy umieścić Adama Jerzego Czartoryskiego ${ }^{45}$. Już na początku XIX w. książę wskazywał, że polityka przeplatana z działaniami wojennymi, którą prowadziły Prusy i Austria, oraz rywalizacja Francji i Anglii prowadziły do destabilizacji sytuacji w Europie i ciągłych konfliktów. Temu stanowi rzeczy mogłoby przeciwdziałać powołanie do życia organizacji międzynarodowej, konfederacji państw europejskich pod przewodnictwem Rosji. W tę koncepcję wpisywała się restauracja Polski, będącej przedmiotem szczególnej troski księcia ${ }^{46}$.

$\mathrm{Na}$ sposób uprawiania polityki oraz stosunek ks. Czartoryskiego do wojny miała niewątpliwie wpływ jego refleksja teoretyczna. W Rozważaniach o dyplomacji wskazał na ogólną prawidłowość, zgodnie z którą gdy tylko staje się wy-

43 Ibidem, s. X.

44 S. Smolka, Polityka Lubeckiego przed powstaniem listopadowym, t. 1, Warszawa 1983, s. $182-183$.

45 Zob. A.J. Czartoryski, Pamiętniki i memoriaty polityczne 1776-1809, Warszawa 1986, s. 395 i n.; idem, Dziennik ks. Adama Jerzego Czartoryskiego 1813-1817, Warszawa 2016, passim.

46 S. Barzykowski, op. cit., s. 13, 24-25; A.J. Czartoryski, Dziennik..., passim. 
starczająco silny, polityka zaczyna rozsiewać w nim zalążki chciwości i ambicji. Z kolei gdy naród staje się bardziej ostrożny i ma skromne aspiracje utrzymania pokojowej egzystencji, to jego bierność wzmaga aktywność agresywnych sąsiadów.

Kto wszczyna wojny niesprawiedliwe i krwawe, jeśli nie owa pokrętna dyplomacja, która zimno patrzy na najbardziej oburzające nieprawości? Jako niewzruszony świadek rzezi i zniszczeń, która dokonuje się na naszych oczach, dyplomacja snuje dalej swe chłodne rachuby, sposobiąc się zawczasu do wytłumaczenia ich następstw. Przynosi więcej szkody aniżeli wojna, którą roznieca; duch wojenny zdolny jest ożywić najszlachetniejsze z cnót, duch dyplomatyczny to jedynie chciwość, nieufność i zawiśćc ${ }^{47}$.

Bezpośrednia obserwacja praktyki dyplomatycznej skłoniła księcia do wysnucia pesymistycznych wniosków. U źródeł wojen, które stanowiły środek oddziaływania $\mathrm{w}$ relacjach międzynarodowych, leżała machiaweliczna wizja polityki, oparta na bezwzględnym dążeniu do realizacji partykularnych interesów kosztem innych. Stąd zapewne wynikało jego dążenie do oparcia ładu europejskiego na trwałym porządku instytucjonalnym.

Przyczyn ludzkiej skłonności do toczenia wojen poszukiwał Stanisław Staszic. Przedmiotową problematykę poruszył na dwóch płaszczyznach: bieżącej polityki oraz $\mathrm{W}$ wymiarze historiozoficznym. W zmienionej po wojnach napoleońskich sytuacji politycznej myśliciel powrócił do relacji wojny i polityki, którą pierwotnie podjął w związku z tą toczącą się podczas Sejmu Wielkiego. Rozważania poświęcone skutkom wojny wpisywały się w refleksję o organizacji ładu europejskiego po wojnach napoleońskich. W sierpniu $1815 \mathrm{r}$. na posiedzeniu Warszawskiego Towarzystwa Przyjaciół Nauk wygłosił referat nt. „Myśli o równowadze politycznej w Europie". Punktem wyjścia było stwierdzenie, że pomimo deklaracji trudno w dziejach wskazać choćby pół wieku względnego spokoju. Dzieje się tak, gdyż państwa podlegają ciągłym przemianom, a procesom tym towarzyszą konflikty" ${ }^{48}$.

W sytuacji względnie ukształtowanego porządku europejskiego pojawienie się nowych bytów politycznych (Staszic miał na myśli przede wszystkim Rosję) musiało skutkować zmianą sytuacji geopolitycznej. Państwom europejskim zarzucił, że nie tylko nie podjęły żadnych działań powstrzymujących rozrost nowych potęg, ale także niejednokrotnie swoimi posunięciami potęgowały ten proces. W konsekwencji musiało dojść do naruszenia status quo ${ }^{49}$.

Po doświadczeniach wojen napoleońskich nadszedł czas rozmów o nowym porządku w Europie. O ile intencje przyświecające zwołaniu kongresu wiedeń-

47 A.J. Czartoryski, Rozważania o dyplomacji, Kraków 2011, s. 35.

48 S. Staszic, Myśli o równowadze politycznej w Europie, [w:] idem, Pisma filozoficzne i społeczne, Warszawa 1954, s. 301.

49 Ibidem, s. 302. 
skiego Staszic uznawał za słuszne, o tyle już założenia nowego ładu oceniał krytycznie. Zamiast powrotu do układu sił, w którym byłoby miejsce dla Polski, negocjujący uznali, iż dysponują carte blanche i w sposób arbitralny mogą dzielić terytoria i wyznaczać granice państw oraz własne strefy wpływów. W konsekwencji Polacy stali się przedmiotem targów politycznych ${ }^{50}$.

Rozważania Staszica wiązały się z dojrzewającą w nim ideą słowianofilstwa, stanowiącą grunt teoretyczny dla procesu połączenia Słowian pod carskim berłem przy wiodącej roli narodu polskiego i rosyjskiego. Zjednoczenie miałoby stać się fundamentem równowagi politycznej na kontynencie. „Połączenie, zrzeszenie się Słowian w Cesarstwie Rosyjskim sprowadzi zrzeszenie się Europy, zniszczy w niej wojny i nada tej części świata stały pokój” ${ }^{\prime 51}$. W ten sposób, reprezentując słabszą stronę relacji polsko-rosyjskich, dążył do upodmiotowienia Polaków w nowej sytuacji politycznej. Eksponowanie w koncepcji integracyjnej ich znaczącej roli świadczy z jednej strony o predylekcjach etnocentrycznych i megalomanii narodowej, z drugiej natomiast może stanowić dowód realizmu politycznego myśliciela, który w niekorzystnej dla sprawy polskiej sytuacji politycznej próbował zaproponować koncepcję pozwalającą ochronić resztki polskiej podmiotowości.

Szerszy kontekst historiozoficzny dla rozważań o wojnach znalazł się w opublikowanym w 1819 r. dziele Ród ludzki. Staszic dowodził w nim, że skłonność do walki została wpisana w konstrukcję psychofizyczną człowieka. Pierwsze walki toczył z dzikimi zwierzętami o przetrwanie. Dzięki swojej kreatywności ludzie konstruowali narzędzia, które pozwoliły im z czasem uzyskać przewagę nad lepiej wyposażonymi przez naturę zwierzętami ${ }^{52}$. Z kolei do pierwszych walk między ludźmi doszło, gdy myśliwi zapragnęli odebrać majątek pasterzom. Na początku były to wojny łupieskie. $Z$ czasem celem stało się zabijanie i niewolenie. To okres, kiedy „człowiek zaczyna być nieprzyjacielem człowieka" ${ }^{3}$.

Pasterze poprzez okiełznanie zwierząt uszczuplili zasoby myśliwych. Z kolei łowcy, lepiej posługujący się bronią, zaczęli grabić pasterzy i zabierać im wyniki ich pracy, w ten sposób wstrzymując postęp. Zdaniem Staszica był to szczególny przypadek ogólniejszej prawidłowości. Ci, którzy korzystają najpełniej z istniejącego porządku, zawsze stanowią przeszkodę dla zmian naruszających korzystne status quo ${ }^{54}$.

Specyfika konfliktów zbrojnych zmieniła się wraz z ukształtowaniem się ustroju monarchicznego, zdominowanego przez interesy szlachty i duchowieństwa. Elity podjęły wtedy próbę znalezienia uzasadnienia moralnego dla wojen, wyrażającego interesy warstw uprzywilejowanych. „Moralność zasadzona na ob-

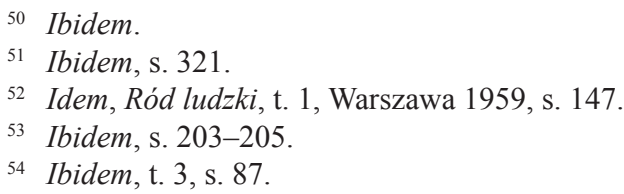


rządkach nie zostawia człowiekowi sumienia, ułatwia możnych zbrodnie, wstrzymuje tylko słabych winy" 55 . W konsekwencji naganne stało się nie to, co naruszało prawo natury, lecz to, co było sprzeczne z normami ustanowionymi arbitralnie w imię interesu rządzących. Wojny przestały mieć uzasadnienie „użytecznościowe". Kluczowy stał się interes władcy i jego zaplecza politycznego, wspólnie monopolizujących korzyści wynikające z ich prowadzenia. „Natura wojnę podała ludziom za ostateczny i najdzielniejszy sposób obrony swoich praw i do oswobodzenia się spod gwałtu vel gwałcicielów. Samodzierze towarzystwa nadały wojnom za jedyny cel panowanie gwałcicielów vel samodzierżów bezpieczeństwo, a ludów niewolę" ${ }^{56}$. Od tego czasu, kontynuował Staszic, społeczeństwa traciły i cierpiały w wyniku wojen, a zyskiwali władcy. Jednocześnie negatywne skutki działań zbrojnych dosięgały niewinnych, nigdy zaś tych, którzy je wywoływali.

Do grupy umiarkowanych polityków i myślicieli Królestwa Polskiego należy zaliczyć Stanisława Kostkę Potockiego. W kontrowersyjnym dziele Podróż do Ciemnogrodu w zawoalowanej formie dokonał analizy przyczyn słabości i upadku Rzeczypospolitej. Zwracając uwagę na znaczenie obronności, wskazał na pożądany kierunek reform, który powinni przyjąć Polacy marzący o suwerenności. W literackiej formie polityk wskazał implicite podstawowe założenia wizji ustrojowej państwa, której integralny element stanowiła zinstytucjonalizowana siła zbrojna ${ }^{57}$.

\section{WOJNA W ŚWIETLE ROZWAŻAŃ NAUKOWYCH}

Pośród polskich prawników początku XIX w. stosunkowo wiele uwagi wojnie poświęcił Franciszek Ksawery Szaniawski ${ }^{58}$. Jego poglądy na temat bezpieczeństwa publicznego oraz konfliktów militarnych w znacznym stopniu zostały ukształtowane przez rozbiory oraz okres wojen napoleońskich. Obserwacja przebiegu i skutków tych wydarzeń spowodowała, że uznawał ochronę mieszkańców przed niebezpieczeństwami płynącymi z zewnątrz za jedno z głównych zadań władzy. Państwa nie egzystują w próżni. Uprawianie polityki na arenie międzynarodowej powoduje, że stają się partnerami albo rywalami. Szaniawski akcentował konieczność poszanowania niezawisłości każdego państwa oraz utrzymanie partnerskich relacji. Standardy te wiązał z zasadą suwerenności oraz równością, wywiedzionymi z prawa natury. W celu ochrony przed zagrożeniem zewnętrznym państwa dysponują dwoma instrumentami: dyplomacją i armią. Myśliciel przyznał prymat pierwszemu z nich ${ }^{59}$.

\footnotetext{
55 Ibidem, t. 2, s. 297-298.

56 Ibidem, s. 299.

57 S.K. Potocki, Podróż do Ciemnogrodu, Wrocław 1955, passim.

58 Zob. R. Kania, Myśl polityczno-prawna Franciszka Ksawerego Szaniawskiego, Płock 2012.

59 F.K. Szaniawski, Statyka prawa, czyli nauka porównywań w prawie przez X. Szaniawskiego D.O.P. i Professora w Królewsko-Warszawskim Uniwersytecie, Warszawa 1819, s. 56-59.
} 
Szaniawski uznawał konflikt za naturalny element życia zbiorowego, który występuje na każdym szczeblu relacji międzyludzkich. Pomimo tego, że powoduje wiele nieszczęść, zazwyczaj stanowi skutek świadomych działań. Ludzie, kierując się pobudkami egoistycznymi, mają skłonność do naruszania uprawnień innych, przedkładając potencjalne korzyści własne ponad wyrządzoną krzywdę. Predyspozycje do agresji i żądzy władzy wywołują pragnienie dominacji nad innymi, a przemoc stanowi powszechny sposób realizacji celów. Myśliciel pytał retorycznie: „Czyliż człowiek ma być najsroższym nieprzyjacielem człowieka? Czyliż na to Panie posadziłeś nas na ziemi, abyśmy samych siebie wyniszczali srodze?" ${ }^{60}$.

W ocenie wojen Szaniawski stanął na stanowisku etyki chrześcijańskiej. Pomimo naturalnego podłoża, jak twierdził, wojna pozostaje w sprzeczności z miłością bliźniego. Chociaż konflikty zbrojne naruszają prawo Boże, to czasem Bóg do nich dopuszcza ${ }^{61}$. Ten stan rzeczy wymusza na państwach określone działania, dlatego:

[...] trzeba utrzymywać w bojaźni złych i burzliwych ludzi, trzeba nieposłusznych przymuszać do powolności, aby pełnili właściwe im obowiązki, trzeba mieć siłę czynną i przerażającą, trzeba na nieszczęście ludzkości moc mocą odeprzeć, trzeba być gotowym do wojny, gdy ta konieczną staje się, gdy jej uniknąć nie można. Każdy bronić powinien ojczyzny swojej przeciw wewnętrznym i zewnętrznym nieprzyjaciołom ${ }^{62}$.

Pochodząca z poboru armia obywatelska zapewnia wojsku dzielność oraz upowszechnia znajomość sztuki wojennej. Dzięki temu w nagłej potrzebie wielu obywateli może brać czynny i skuteczny udział w obronie ojczyzny. Rozwiązanie to dawało gwarancję faktycznego zaangażowania żołnierzy w obronę państwa, ponieważ interes prywatny walczących wiązał się ściśle z interesem państwowym ${ }^{63}$.

W niewielkim stopniu problematyka wojenna absorbowała luminarzy polskiej myśli społeczno-ekonomicznej. Jeżeli zagadnienie to w ogóle pojawiało się w ich rozważaniach, to stanowiło element tła dla innych zagadnień. Pierwszy z podejmujących ówcześnie zagadnienia ekonomiczne Wawrzyniec Surowiecki, analizując okoliczności powodujące ograniczenie przyrostu ludności, wskazywał na przyczyny naturalne i społeczne. W drugiej kategorii jako kluczowe wymienił wojny ${ }^{64}$. Skłonności do agresji doszukiwał się w naturze ludzkiej. Twierdził, iż „natura tworzy wojownika, nauki robią sędziego, administrator zaś sam się usposabiać musi" ${ }^{65}$. Pomimo naturalnego charakteru wojen ich szczególnej mocy

${ }^{60}$ Idem, Kazania, t. 1, Warszawa 1819, s. 210-211.

${ }^{61}$ Ibidem.

${ }^{62}$ Ibidem, s. 373-374.

${ }^{63}$ Idem, Statyka prawa..., s. 54-56.

64 J. Grzywicka, A. Łukaszewicz, Wstęp, [w:] W. Surowiecki, Wybór pism, Warszawa 1957, s. XLI.

65 W. Surowiecki, O statystyce Księstwa Warszawskiego, [w:] idem, Dzieła, Warszawa 1957, s. 276. 
destrukcyjnej upatrywał w rozejściu się dróg refleksji religijnej i naukowej, bowiem to „epoka ostatecznego rozdwojenia wydziału moralnego była epoką najokropniejszej burzy, wojen i zaciekłości”"66.

Surowiecki z troską wspominał o przyjmowaniu błędnych założeń w polityce międzynarodowej. Wielu rządzącym wydawało się niemożliwe budowanie własnego szczęścia inaczej niż kosztem innych państw i narodów. Przez wieki zazdrość o zasobność innych była przyczyną nieufności i wojen. Ze smutkiem myśliciel konstatował, że Europejczycy, którzy szczycili się najwyższym poziomem cywilizacji i kultury, najbardziej zhańbili się nieprawością skutkującą utrwaleniem dominacji silniejszych nad słabszymi ${ }^{67}$.

Poszukując przyczyn wpływających na gotowość ludności do podjęcia obrony ojczyzny, Surowiecki wskazał na kluczowe znaczenie statusu członków społeczeństwa. W „kraju niewolników” nie ma wielu patriotów. W konsekwencji jest on słaby, gdyż „siły jego składają się z szczupłej liczby przywiązanych"68. W podobnym tonie wypowiadał się Dominik Krysiński, stwierdzając, że liczba właścicieli nieruchomości gruntowych stanowi nie tylko dowód wysokiego poziomu rolnictwa oraz dobrego i sprawiedliwego ustroju państwa, ale także pozostaje najlepszym środkiem przywiązania obywatela do ojczyzny i źródeł gotowości do obrony niepodległości. Model sił zbrojnych traktował natomiast jako przedmiot ekonomii politycznej. Podkreślał, iż prowadzenie racjonalnej gospodarki oraz gromadzenie rezerw pozwala łatwiej przetrwać sytuacje kryzysowe, w tym okres wojny ${ }^{69}$.

Również Sarbek - już nie jako historyk, lecz ekonomista - poruszał problematykę obronności:

Naród jako ciało polityczne uważany nie mógłby utrzymać się, gdyby pewnej części dochodów swoich zaspokojeniu potrzeb pospolitych nie poświęcił. Przez potrzeby pospolite, czyli publiczne, rozumiemy [...] utrzymanie wszystkich tych instytucji, od których bezpieczeństwo zewnętrzne i wewnętrzne kraju, porządek i pomyślność pospolita zależą ${ }^{70}$.

Omawiając problem zbytu produkcji narodowej za granicą, zauważył, że jego niski poziom wynika zazwyczaj z niekorzystnej sytuacji politycznej, która hamuje wolność gospodarczą. Pośród negatywnych czynników wymienił konflikty polityczne oraz wojny jako ich najbardziej drastyczny przejaw. Uważał, że dopóki państwa będą się siebie wzajemnie obawiać, dopóty stan gospodarki narodowej będzie niepewny ${ }^{71}$.

66 Ibidem, s. 345.

${ }^{67}$ Ibidem, s. 194-195, 274-275.

68 Idem, O upadku przemystu i miast w Polszcze, [w:] idem, Dzieła, s. 191.

69 Idem, Uwagi względem poddanych w Polszcze i projekt do ich uwolnienia, [w:] idem, Dzieta, s. 11, 18; idem, O upadku przemystu..., s. 61.

70 F. Skarbek, Ogólne zasady nauki gospodarstwa narodowego, t. 2, Warszawa 1955, s. 206.

71 Ibidem, s. 82, 88, 164. 
Pośród praktyków, będących jednocześnie członkami elit politycznych, którzy poruszali zagadnienia obronności, należy wskazać prezesa komisji województwa mazowieckiego Rajmunda Rembielińskiego ${ }^{72}$. Organizację rozwiązań chroniących przed zagrożeniem zewnętrznym polityk ten uznawał za jedno z podstawowych zadań państwa. Podkreślał, że obowiązek ów obejmuje nie tylko ochronę integralności osoby ludzkiej, ale również jej majątku ${ }^{73}$, czym nawiązał do wcześniejszej wypowiedzi Stanisława Węgrzeckiego ${ }^{74}$.

\section{WOJNA W PIŚMIENNICTWIE PUBLICYSTYCZNYM}

Interesujący ślad refleksji dotyczącej wpływu wojny na światopogląd ówczesnych stanowi anonimowa opinia zamieszczona w „Pamiętniku Warszawskim” dotycząca ogłoszenia konkursu przez Akademię w Erfurcie. Zadanie polegało na udzieleniu odpowiedzi na pytania: „Jaki okazała wpływ wojna oswobodnicza z lat 1813-1815 na człowieczeństwo uważane w całej jego czystości? Czyli wojna ta przybliżyła go do swego celu lub też od niego odsunęła?"75. Autor opinii krytycznie wypowiedział się na temat konstrukcji pytań konkursowych oraz zakwestionował zasadność powiązania dwóch odległych od siebie pojęć: człowieczeństwa i wojny. Wskazał też na wieloznaczność pierwszego z nich oraz skrytykował europocentryczny punkt widzenia formułujących pytania, usiłujących ukazać kontynentalny punkt widzenia jako pogląd uniwersalny. Jeżeli nawet wojny zmieniają postawy ludzkie, to trudno wykazać rzeczywisty związek przyczynowo-skutkowy między nimi. $Z$ drugiej strony autor wskazał na reperkusje ostatnich wojen. Za dwa najważniejsze skutki polityczne uznał restaurację dynastii Burbonów we Francji i niepodległość kolonii hiszpańskich w Ameryce. Skutki wojny, konkludował, miały zatem przede wszystkim charakter polityczny. Zasiały też ziarno niepokoju, którego przyszłe skutki trudno przewidzieć, na proces dziejowy oddziałuje bowiem szereg czynników, których wpływ trudno jednoznacznie określić. W takim przypadku łatwo o nietrafne oceny, gdyż procesy dziejowe zachodzą w długim horyzoncie czasowym. Dlatego zadanie wspomnianych pytań konkursowych miałoby sens, gdyby zostały sformułowane nie w 1817 r., lecz w 1917 r. $^{76}$

72 Zob. R. Kania, Usprawnić państwo. Myśl spoteczno-polityczna Rajmunda Rembielińskiego, Płock 2015.

73 R. Rembieliński, Gtos w dyskusji nad projektem ustawy „O normalnym rozgraniczaniu dóbr wszystkich nieruchomych gruntowych", [w:] Rajmund Rembieliński. Jego czasy i jego wspótcześni, red. A. Barszczewska-Krupa, Warszawa 1989, s. 202-203.

74 S. Węgrzecki, Rozprawa o profesjach i profesjonalistach oraz systemacie administracyjnym, Warszawa 1810, s. 111.

75 Nowina literacka, „Pamiętnik Warszawski” 1817, t. 8, s. 485.

76 Uwagi nad zadaniem Akademii pożytecznych nauk w Erfurcie, o wplywie woyny $w$ latach 1813-1815 na ludzkość, ogłoszonem w pamiętniku Warsz. w tomie VIII. na K. 485, „Pamiętnik Warszawski” 1817, t. 9, s. 447-456. 
Rozważania poświęcone problematyce wojny i obronności znalazły się również w utopii Podróż do Kalopei Wojciecha Gutkowskiego. Na poglądach autora zaważyło ukończenie Korpusu Inżynierów oraz udział w insurekcji kościuszkowskiej. Głównym celem dzieła było zaprojektowanie wizji społeczeństwa doskonałego. W tę koncepcję wpisała się także wojna i obronność wymyślonego państwa. Autor dostrzegł znaczenie wojen obronnych oraz potępił wojny napastnicze. Dużą wagę przywiązywał do strategii odstraszania ${ }^{77}$. Z uwagi na to, iż przedstawiona Warszawskiemu Towarzystwu Przyjaciół Nauk praca nie znalazła uznania w oczach recenzenta Stanisława Węgrzeckiego ${ }^{78}$, wpływ poglądów Gutkowskiego na opinię publiczną należy uznać za marginalny.

\section{WOJNA W OBLICZU NARASTAJĄCEGO RADYKALIZMU}

Tajne stowarzyszenia, których celem była zbrojna walka o niepodległość, zaczęły powstawać niezależnie od siebie od 1819 r. we wszystkich częściach kraju, obejmując różne warstwy społeczne ${ }^{79}$. Ich postawy formowała idea wojny. Przywódcy Towarzystwa Patriotycznego: Łukasiński, Machnicki i Szreter - walczyli w armii Księstwa Warszawskiego przeciwko Austrii w 1809 r., a także odbyli kampanię wojenną 1812-1813. Mieli zakodowane przeświadczenie o konieczności podjęcia walki o niepodległość Polski. Zdaniem Barzykowskiego działalność konspiracyjna nie była wyłącznie wynikiem specyficznej sytuacji Polaków, lecz również efektem „ducha czasu unoszącego się nad Europą"80.

Ocena stanu sprawy polskiej pierwszego przywódcy Towarzystwa Patriotycznego, Waleriana Łukasińskiego ${ }^{81}$, odznaczała się trzeźwą oceną. Doceniał zmiany ustrojowe, jakie zaszły na ziemiach polskich w $1815 \mathrm{r}$. Walkę zbrojną widział w dalszej przyszłości. W spisanych pod koniec życia w carskim więzieniu wspomnieniach Łukasiński wyraził pogląd, że zarówno Aleksander I, jak i Napoleon chcieli przywrócenia państwa polskiego. Motywacja pierwszego wynikała z realizacji własnych interesów, drugi zaś dążył do zbudowania równowagi sił w Europie. Napoleon eksploatował Polaków, nie dając w zamian żadnej gwarancji realizacji ich aspiracji. Polacy wypełniali jednak jego wolę gorliwie i bez przymusu, gdyż:

[...] tak ten oszust potrafił oczarować Polaków, że dziś nawet imię jego w pałacu bogacza i w ubogiej chatce jest wspominanym z błogosławieństwem, zamiast że imiona Aleksandra, Kon-

77 W. Gutkowski, Podróż do Kalopei, Warszawa 1956, passim.

78 Z. Gross, Wstęp, [w:] W. Gutkowski, op. cit., s. 11 i n.; Z. Najdowski, ,Podróż do Kalopei”" Wojciecha Gutkowskiego. Studium z dziejów myśli polskiego Oświecenia, Warszawa 1988, s. 7-8.

79 S. Barzykowski, op. cit., s. 213.

80 Ibidem, s. 182-183, 242-243.

81 R. Gerber, Wstęp, [w:] W. Łukasiński, Pamiętnik, Warszawa 1986, s. 5-6, 9. 
stantyna i Mikołaja powtarzane są z nienawiścią i przeklęstwem, chociaż ci książęta mieli więcej sposobów i czasu działania nam dobrego ${ }^{82}$.

Łukasiński rozumiał też agresywną naturę caratu: „Rosja jest państwem jednowładnym i wojskowym, a zatem duch i dążność jej - wojna i zdobycia"»3.

Po klęsce Napoleona wojsko polskie znalazło się pod protekcją Aleksandra I i - jak wspomina Łukasiński - ,śmiało i wesoło powracało do kraju”, korzystając z dobroci wspaniałomyślnego cara. Jednak oddane pod komendę księciu Konstantemu, służyło carewiczowi dla rozrywki: „Tak jak lalka służy do zabawy małej dziewczynie, która je rozbiera i ubiera co moment, tak w. książę Konstanty przemieniał ubiór, porządek i manewra wojska" ${ }^{\prime 4}$.

Rolę wolnomularstwa narodowego, w szczególności Towarzystwa Patriotycznego Łukasińskiego, docenił Mochnacki. Pomimo tego, że szybko upadło, przygotowało ono mentalnie Polaków (głównie wojskowych) do podjęcia zbrojnej walki o niepodległość przeciwko caratowi ${ }^{85}$. Jednocześnie uważał, że jego członkowie zbyt wiele czasu poświęcali na przygotowania do walki, ignorując fakt, że najskuteczniejszym narzędziem prowadzenia walki jest wybór optymalnego momentu. Brak rozpoczęcia działań we właściwym czasie powodował szkody dla sprawy narodowej. Każda konspiracja musiała się bowiem kiedyś zmienić w otwartą walkę ${ }^{86}$.

Istotną rolę dla radykalizacji nastrojów prowadzących do powstania zbrojnego odegrał Sąd Sejmowy. Obrady i wyrok skazujący przywódców Towarzystwa Patriotycznego przeniósł problematykę walki o niepodległość z dyskretnych dyskusji zaufanych osób na płaszczyznę debaty elektryzującej opinię publiczną ${ }^{87}$. Duże znaczenie dla kształtowania oraz radykalizacji nastrojów podczas rozpatrywania sprawy oskarżonych członków Towarzystwa Patriotycznego miał anonimowy druk ulotny (jak się później okazało pióra Mochnackiego) Głos obywatela z Poznańskiego do senatu Królestwa Polskiego z okazji Sądu Sejmowego. Autor podkreślił, że odpowiedzialni za rozbiory Rzeczypospolitej starali się wykazać nieprawość myślenia o ponownym połączeniu ziem polskich. Rosja od stu lat mieszała się w wewnętrzne sprawy Polski, wykorzystując wszystkie dostępne metody, w tym przemoc zbrojną. Zaakcentował, że dążenie do niepodległości to „najpierwsze prawo jest przyrodzone, nadane od Boga słabszym ku obronie przeciw silniejszym" $"$.

82 W. Łukasiński, op. cit., s. 32.

83 Ibidem, s. 90.

84 Ibidem, s. 43-44.

85 M. Mochnacki, Powstanie..., s. 230.

86 Ibidem, s. 275.

87 S. Barzykowski, op. cit., s. 219-220.

88 M. Mochnacki, Gtos obywatela z Poznańskiego do senatu Królestwa Polskiego z okazji Sądu Sejmowego, [w:] idem, Powstanie..., s. 338-339, 341, 343-344. 
Analizując nastroje społeczne w Królestwie Polskim, należy zauważyć, że pogląd o nieuchronności walki zbrojnej z caratem podzielali nie tylko radykaliści. Także zdaniem bardziej umiarkowanego Barzykowskiego po 1825 r. walka zbrojna w obronie swobód Królestwa Polskiego stała się nieunikniona wobec naruszeń jego autonomii przez carat. Rosja po zwycięstwie nad Napoleonem jawiła się jako potęga niezwyciężona, dlatego realiści starali się znaleźć sposoby uniknięcia konfliktu zbrojnego ${ }^{89}$. Mimo takiego stanowiska konsekwentnie twierdził, iż powstanie nie było dziełem narodu, lecz garstki zradykalizowanych podoficerów i młodzieży akademickiej ${ }^{90}$.

Zbliżone stanowisko zajął Skarbek. Jego zdaniem ciąg zdarzeń prowadzących do wybuchu powstania stanowił proces naturalny w swoim przebiegu. Trudno oczekiwać od narodu poniżonego i pokonanego, aby zaprzestał dążeń do niepodległości, także na drodze walki zbrojnej. Znaczna część dziejów Królestwa Polskiego była swego rodzaju wstępem do wojny. Wzmocnieniem tej tendencji była nieprzejednana postawa części rosyjskich elit, dążących do całkowitego wchłonięcia ziem polskich przez Imperium. Brutalne dążenie do dominacji musiało doprowadzić Polaków do równie bezkompromisowej obrony resztek niezależności ${ }^{91}$.

Według Mochnackiego wojna przeciwko zaborcom (przede wszystkim Rosji), jako ścieżka prowadząca do niepodległości, stanowiła fundament polskiej racji stanu. Kolejne powstania i konfrontacja z sąsiednimi mocarstwami nie tylko nie zniechęcały, lecz przeciwnie - wpływały na wzrost determinacji narodu do prowadzenia dalszej walki ${ }^{92}$. Problemem, na który wskazywał, była nadmierna skłonność Polaków do zbyt długich dysput przed podjęciem działań ${ }^{93}$.

Dokonując post factum analizy genezy i przebiegu powstania listopadowego, Mochnacki wyraził przekonanie, że wszelka walka przeciwko Rosji musi okazać się bezskuteczna dopóki carat będzie kontrolował ziemie zagarnięte podczas kolejnych zaborów. Podkreślił, iż na terenie Królestwa można jedynie bronić się i zginąć mężnie. Dlatego głównym teatrem wojny powinny być Litwa i Ukraina. Ponadto, z uwagi na dysproporcję sił, Polacy powinni podejmować działania niekonwencjonalne, odbiegające od ówczesnej sztuki wojennej ${ }^{94}$.

Mochnacki eksponował podwójną specyfikę przygotowywanych działań zbrojnych narodu polskiego. Była to jednocześnie rewolucja i restauracja. Nie należało tego stanowiska traktować jako chęci powrotu do stanu sprzed $1772 \mathrm{r}$. Przyszła Polska miała być nowoczesna i zamieszkiwana przez nowoczesny naród.

\footnotetext{
89 A. Ër[...], Do czytelnika, [w:] S. Barzykowski, op. cit., s. LVI.

Ibidem, s. XXII-XIII.

F. Skarbek, Dzieje Polski..., s. 211, 299-300.

M. Mochnacki, Powstanie..., s. 51, 54-55.

Ibidem, s. 213.

Ibidem, s. 59-61.
} 
Walka o niepodległość wymagała pełnej determinacji oraz wykorzystania wszystkich dostępnych sił i środków. A potencjał tkwił głównie w ludności chłopskiej. Dlatego jako drugi obok niepodległości cel walki wskazywał uregulowanie sprawy chłopskiej. Mówiąc zatem o restauracji, myślał o przywróceniu dawnych granic państwa. Rewolucja natomiast miała przynieść odmienną organizację ustroju politycznego i społeczno-gospodarczego $0^{95}$.

Walka zbrojna przeciwko Rosji w ówczesnych warunkach miała szansę powodzenia. Od wstąpienia na tron Mikołaja I carat doznał pasma klęsk militarnych, co prowadziło do osłabienia zdolności bojowych armii rosyjskiej oraz wyczerpania zasobów finansowych. Ponadto wojsko trapiły epidemie i głód. W konsekwencji, według analiz Mochnackiego, car dysponował bardzo ograniczonymi siłami zbrojnymi w europejskiej części Imperium. Rozpoczęciu walki zbrojnej sprzyjała również sytuacja w zachodniej części kontynentu, zwłaszcza rewolucja lipcowa we Francji. W Warszawie, jak twierdził, wszyscy przeczuwali, że musi dojść do przesilenia prowadzącego do walki zbrojnej także w Polsce: „Na koniec cała Warszawa zaczęła mówić o rewolucji, jakby sto sześćdziesiąt tysięcy ludzi do jednego związku, do jednej konspiracji należało"

Oceniając postawę ludności - nie tylko Warszawy, lecz również Królestwa Polskiego - tuż przed i w chwili wybuchu walk, Mochancki był przekonany, że zapał wojenny był powszechny. Do walki garneli się wszyscy, niezależnie od pozycji społecznej i wieku. Był to potencjał, którego właściwe wykorzystanie dawało realną szansę powodzenia wojny polsko-rosyjskiej, w szczególności uwzględniając stan i morale polskiego wojska ${ }^{97}$. Błędów upatrywał w przywództwie, w tym w braku wizji nowego rządu, którą powinni mieć powstańcy. Tymczasem sprzysiężenie Wysockiego obok wywołania powstania nie miało żadnej spójnej koncepcji dalszej walki i planu politycznego. W konsekwencji początkowe działania wojenne były jedynie przejawem improwizacji niewielkiej części radykalnie myślącego wojska i cywilów. Byli to ludzie zbyt mało znani, aby mogli od razu wzbudzić powszechną ufność Polaków ${ }^{98}$.

Wybuch powstania wpłynął na radykalizację postaw i ocen Mochnackiego. Stwierdził wtedy, że decyzja o utworzeniu Królestwa Polskiego podczas kongresu wiedeńskiego stanowiła wynik męstwa i krwi oraz cnót walczących Polaków. Pomimo nadania konstytucji przez Aleksandra I jej zapisy były przez 15 lat nieustannie gwałcone przez satrapów i służalców rosyjskich. Podjęcie walki zbrojnej stanowiło skutek doprowadzenia narodu polskiego do ostateczności przez panujące bezprawie. „Walczymy dla usunięcia od rządu ludzi

\footnotetext{
95 Ibidem, s. 80-81.

96 Ibidem, s. 108, 111, 317, 331.

97 Ibidem, s. 115.

98 Ibidem, s. 320-322, 437.
} 
nikczemnych, zaprzedanych, dla porażenia szpiegów, dla pociągnięcia do odpowiedzialności złodziejów [...]. Walczymy nareszcie dla wspierania i utrzymania tego wojska naszego, które tak piękny przykład nam daje"99. Wystąpienie narodu polskiego uznał za ważniejsze aniżeli rewolucja lipcowa we Francji oraz powstanie w Belgii. Tam bowiem chodziło o udoskonalenie istniejącego ustroju politycznego, tymczasem ,egzystencja polityczna jest jedynym i głównym celem naszego powstania"100. Powstanie nie zmierzało tylko do rewolucji społecznej, lecz także do suwerenności.

Walka zbrojna Polaków wpisywała się w konfrontację dwóch modeli ustroju politycznego: „rządu konstytucyjnego i despotyzmu”, rywalizujących ze sobą w Europie od 1789 r. Powstanie, jak twierdził Mochnacki, wpisywało się w szerszą walkę przeciw despotyzmowi ${ }^{101}$. Nie zapominał przy tym o szczególnym celu Polaków, stwierdzając, iż „restauracja jest celem, a rewolucja środkiem naszego powstania. [...] Restauracja jest w tym: żeby być!, a zaś rewolucja w tym: jak być! Jakim sposobem i kształtem?"102.

Z tymi poglądami polemizował Barzykowski. Uważał, że przyczyną wybuchu powstania nie była walka o niepodległość, lecz nieustanne szarganie honoru żołnierza polskiego przez carewicza ${ }^{103}$. Wskazał też, że znaczna część społeczeństwa w ogóle nie była zainteresowana walką. Za szczególną grupę frakcji ugodowej uznawał elity rządzące, które nie miały nic wspólnego ze spiskowcami. Część z nich przyłączyła się do walki lub znalazła się na czele powstania dopiero w wyniku rozwoju wypadków ${ }^{104}$. Powstanie było dziełem wąskiej grupy spiskowców ${ }^{105}$. Podzielał natomiast pogląd Mochnackiego, że do znacznej radykalizacji nastrojów w armii przyczyniła się rewolucja lipcowa oraz pogłoski o wykorzystaniu wojsk Królestwa Polskiego przeciw Francji ${ }^{106}$.

Sceptycznie nastawiony do radykalnych działań Skarbek stwierdził, iż spiskowcy przygotowujący walkę o niepodległość opierali swoje kalkulacje wyłącznie na przekonaniu o słuszności swojej sprawy, przecenianiu własnych możliwości oraz nadziei na pomoc zewnętrzną, licząc przy tym na wsparcie Opatrzności. Stanowisko opinii publicznej nie zostało ukształtowane na podstawie rzetelnej analizy sytuacji, lecz w wyniku postawy życzeniowej i gwałtownych emocji. Odrzucenie rozumowania racjonalnego wytworzyło przekonanie, że walka zbrojna

99 Idem, Odezwa do mieszkańców stolicy, [w:] idem, Pisma krytyczne i polityczne, t. 2, Kraków 1996, s. 20-21.

${ }^{100}$ Idem, Co rozumieć przez Rewolucję w Polszcze?, [w:] idem, Pisma krytyczne..., s. 25.

${ }^{101}$ Ibidem, s. 26-27.

${ }^{102}$ Idem, Restauracja i rewolucja, [w:] idem, Pisma krytyczne..., s. 79, 83.

${ }^{103}$ A. Ër[...], op. cit., s. XXXIII-XXXIV.

${ }^{104}$ Ibidem, s. XXXV.

${ }^{105}$ S. Barzykowski, op. cit., s. 254-257.

106 Ibidem, s. 260 i n., 274-276. 
o utrzymanie bytu Królestwa Polskiego jest nieuchronną i jedyną drogą do realizacji aspiracji Polaków ${ }^{107}$.

Z perspektywy wieloletniego pobytu w więzieniu carskim stary Łukasiński doszedł do wniosku, że rządy Mikołaja I przynoszące Polakom ogromne rozczarowanie skierowały ich na prostą drogę ku walce zbrojnej. ,Cóż więc zostało Polakom? Otwarta wojna z tyranią"108. Powstania nie uważał bynajmniej za przejaw rozpaczy, braku rozsądku czy brawury. Był przekonany, że gdyby Polacy nadal znosili cierpliwie rosyjskie jarzmo, w Europie utrwaliłoby się przekonanie, że akceptują stan niewoli.

\section{PODSUMOWANIE}

Przeprowadzona analiza skłania do wniosku, iż konstytucyjny okres Królestwa Polskiego został naznaczony problematyką wojny w stopniu istotnym, chociaż nie zawsze związek między przedmiotową problematyką i sytuacją Królestwa Polskiego był wyraźny. Świadczy o tym treść przedstawionych w zarysie poglądów reprezentatywnych przedstawicieli polskiej myśli politycznej. Jako trafny należy uznać pogląd, że w samych założeniach powstania Królestwa Polskiego istniał nierozwiązywalny dualizm ${ }^{109}$. Ustrój liberalny zdefiniowany w konstytucji nie wyrażał pełni rzeczywistości politycznej kraju. Bardzo istotną rolę odgrywał milcząco uznany aksjomat polityczny, iż ta część ziem polskich stanowi zdobycz wojenną Rosji i jako taka podlega nieograniczonej władzy cara. Realny ustrój opierał się częściowo na konstytucji, a częściowo na prawie silniejszego, czego uosobieniem była samowola carewicza Konstantego. Te dwa aspekty: legalny i realny - wpływały na przyjmowanie przez stronę polską i rosyjską odmiennych założeń odnośnie do oceny sytuacji politycznej Królestwa. Istniejący stan rzeczy prowadził do otwartego konfliktu.

Stosunek mieszkańców kraju do wojny można usystematyzować podług pozycji zajmowanej w społeczeństwie. Pierwszą grupę stanowili wpływowi reprezentanci elity rekrutującej się spośród weteranów wojennych lub polityków doby Księstwa Warszawskiego i wojen napoleońskich. Doświadczenia układały się często w trudne i traumatyczne wspomnienia, w szczególności przy ich zestawieniu z komfortowymi warunkami życia elit władzy. Za symbol tego sposobu myślenia może uchodzić doświadczenie, pozycja społeczna, stan zdrowia oraz poglądy namiestnika Zajączka. Ludzie jego pokroju, dążąc do utrzymania uprzywilejowanej pozycji, wykazywali gotowość do podejmowania wszelkich służących temu działań. Utrzymanie korzystnego status quo wymagało manifestowania daleko idącej

${ }^{107}$ F. Skarbek, Dzieje Polski..., s. 308-309.

${ }^{108}$ W. Łukasiński, op. cit., s. 58.

109 B. Łagowski, Filozofia polityczna Maurycego Mochnackiego, Kraków 1981, s. 72-73. 
uległości wobec caratu i to niezależnie od tego, czy czynili to w wyniku faktycznego przekonania czy też z racji konformizmu. Pośród wspomnianej grupy kategorią samą w sobie był minister Drucki-Lubecki, który - chociaż uznawany za stronnika Rosji - starał się prowadzić względnie samodzielną politykę.

Niedaleko od ugodowców plasowali się doświadczeni politycy reprezentujący stanowisko umiarkowane, tacy jak ks. Czartoryski i Staszic. Próbowali określić pozycję Polski, która byłaby akceptowalna, zważywszy na aspiracje Polaków, i jednocześnie uwzględniałaby realia polityczne powojennej Europy.

Do grupy osób stygmatyzowanych przez nieodległe wojny należy zaliczyć również niższych rangą oficerów, spośród których zaczęły formować się pierwsze organizacje spiskowe. Wojna, a właściwie wizja przyszłej walki zbrojnej o niepodległość, determinowała postawy przedstawicieli środowisk radykalnych, które doprowadziły z czasem do wybuchu powstania listopadowego. Zarówno żołnierze skupieni wokół Wysockiego, jak i cywilni spiskowcy, tacy jak Mochnacki, drogę do wolności widzieli biegnącą przez pola bitew. Zatem ich tok rozumowania, podobnie jak weteranów-ugodowców, był wyznaczony przez wojnę z tą różnica, że nie stanowiła ona balastu przeszłości, lecz część wizji przyszłości.

Stosunkowo najmniejsze zainteresowanie problematyką wojenną wykazywali organizatorzy i komentatorzy bieżącego życia Królestwa Polskiego, prawnicy i ekonomiści. Wprawdzie zagadnienie konfliktów zbrojnych pojawiało się w orbicie ich zainteresowań, jednak zazwyczaj jako element tła głównego wątku rozważań. Podsumowując, jako uzasadniony należy uznać wniosek, iż w oficjalnym nurcie debaty publicznej doby Królestwa Polskiego wojna nie występowała w stopniu znaczącym. Jednak, jak wynika z przeprowadzonej analizy, przedmiotowa problematyka odegrała kluczową rolę w piętnastoleciu konstytucyjnym Królestwa Polskiego, determinując myślenie polityczne ówczesnych, a w konsekwencji stanowiąc przyczynę bądź skutek prezentowanych poglądów lub podejmowanych działań politycznych.

\section{BIBLIOGRAFIA}

Barzykowski S., Historya powstania listopadowego, t. 1, Poznań 1883.

Czartoryski A.J., Dziennik ks. Adama Jerzego Czartoryskiego 1813-1817, Warszawa 2016.

Czartoryski A.J., Pamiętniki i memoriały polityczne 1776-1809, Warszawa 1986.

Czartoryski A.J., Rozważania o dyplomacji, Kraków 2011.

Dyaryusz Seymu Królestwa Polskiego 1818, t. 1, Warszawa [b.r.w.].

Ër[...] A., Do czytelnika, [w:] S. Barzykowski, Historya powstania listopadowego, t. 1, Poznań 1883.

Gerber R., Wstęp, [w:] W. Łukasiński, Pamiętnik, Warszawa 1986.

Gross Z., Wstęp, [w:] W. Gutkowski, Podróż do Kalopei, Warszawa 1956.

Grzywicka J., Łukaszewicz A., Wstęp, [w:] W. Surowiecki, Wybór pism, Warszawa 1957.

Gutkowski W., Podróż do Kalopei, Warszawa 1956.

Kania R., Myśl polityczno-prawna Franciszka Ksawerego Szaniawskiego, Płock 2012. 
Kania R., Usprawnić państwo. Myśl społeczno-polityczna Rajmunda Rembielińskiego, Płock 2015. Koźmian K., Pamiętniki, t. 3, Wrocław 1972.

Lelewel J., Polska, dzieje i rzeczy jej, t. 7, Poznań 1859.

Linde S.B., Stownik języka polskiego, t. 6, cz. 1, Lwów 1860.

Łagowski B., Filozofia polityczna Maurycego Mochnackiego, Kraków 1981.

Łukasiński W., Pamiętnik, Warszawa 1956.

Mochnacki M., Co rozumieć przez Rewolucję w Polszcze?, [w:] idem, Pisma krytyczne i polityczne, t. 2, Kraków 1996.

Mochnacki M., Głos obywatela z Poznańskiego do senatu Królestwa Polskiego z okazji Sądu Sejmowego, [w:] idem, Powstanie narodu polskiego w roku 1830 i 1831, t. 1, Warszawa 1984.

Mochnacki M., Odezwa do mieszkańców stolicy, [w:] idem, Pisma krytyczne i polityczne, t. 2, Kraków 1996.

Mochnacki M., Powstanie narodu polskiego w roku 1830 i 1831, t. 1, Warszawa 1984.

Mochnacki M., Restauracja i rewolucja, [w:] idem, Pisma krytyczne i polityczne, t. 2, Kraków 1996.

Najdowski Z., „Podróż do Kalopei” Wojciecha Gutkowskiego. Studium z dziejów myśli polskiego Oświecenia, Warszawa 1988.

Niemcewicz J.U., Pamiętniki (1809-1820), t. 2, Poznań 1871.

Nowina literacka, „Pamiętnik Warszawski” 1817, t. 8.

Ogiński M.K., Pamiętniki Michała Ogińskiego o Polsce i Polakach od r. 1788 aż do końca r. 1815, t. 3, Poznań 1870.

Pepłowski F., Stownictwo i frazeologia polskiej publicystyki okresu Oświecenia i Romantyzmu, Warszawa 1961.

Potocki S.K., Podróż do Ciemnogrodu, Wrocław 1955.

Rembieliński R., Głos w dyskusji nad projektem ustawy „, O normalnym rozgraniczaniu dóbr wszystkich nieruchomych gruntowych", [w:] Rajmund Rembieliński. Jego czasy i jego wspótcześni, red. A. Barszczewska-Krupa, Warszawa 1989.

Skarbek F., Dzieje Polski, cz. 2: Królestwo Polskie od epoki początku swego do Rewolucyi Listopadowej, Poznań 1877.

Skarbek F., Ogólne zasady nauki gospodarstwa narodowego, t. 2, Warszawa 1955.

Smolka S., Polityka Lubeckiego przed powstaniem listopadowym, t. 1, Warszawa 1983.

Staszic S., Myśli o równowadze politycznej w Europie, [w:] idem, Pisma filozoficzne i społeczne, Warszawa 1954.

Staszic S., Ród ludzki, t. 1-3, Warszawa 1959.

Surowiecki W., O statystyce Księstwa Warszawskiego, [w:] idem, Dzieła, Warszawa 1957.

Surowiecki W., O upadku przemystu i miast w Polszcze, [w:] idem, Dzieła, Warszawa 1957.

Surowiecki W., Uwagi względem poddanych w Polszcze i projekt do ich uwolnienia, [w:] idem, Dzieła, Warszawa 1956.

Szaniawski F.K., Kazania, t. 1, Warszawa 1819.

Szaniawski F.K., Statyka prawa, czyli nauka porównywań w prawie przez X. Szaniawskiego D.O.P. i Professora w Królewsko-Warszawskim Uniwersytecie, Warszawa 1819.

Szaniawski J.K., Noty do „, O naturze i przeznaczeniu urzędowań w spoleczności”, [w:] Kręte drogi myśli politycznej Józefa Kalasantego Szaniawskiego (1764-1843), oprac. S. Paczos, Poznań 2012.

Szaniawski J.K., Ogólniejsze myśli względem projektowania [Konstytucji Królestwa Polskiego], [w:] Kręte drogi myśli politycznej Józefa Kalasantego Szaniawskiego (1764-1843), oprac. S. Paczos, Poznań 2012.

Uwagi nad zadaniem Akademii pożytecznych nauk $w$ Erfurcie, o wplywie woyny $w$ latach 18131815 na ludzkość, ogłoszonem w pamiętniku Warsz. w tomie VIII. na K. 485, „Pamiętnik Warszawski" 1817, t. 9.

Węgrzecki S., Rozprawa o profesjach i profesjonalistach oraz systemacie administracyjnym, Warszawa 1810. 


\section{SUMMARY}

The constitutional period of the Kingdom of Poland was a relatively calm time between the Napoleonic wars and the November Uprising. In reality yet the problematic of war substantially determined the horizon of public discussion about war in the Polish political thought between 1815 and 1830. Subsequently, the views of a conciliatory, moderate and radical environment were presented. The analysis is supplemented by selected historical narratives and the comments by the representatives of science. Uprising

Keywords: war; the Kingdom of Poland; political thought; Napoleonic wars; the November

\section{STRESZCZENIE}

Okres konstytucyjny Królestwa Polskiego był czasem względnego spokoju między wojnami napoleońskimi i powstaniem listopadowym. W rzeczywistości problematyka wojny w znacznym stopniu wyznaczała jednak horyzont dyskusji o państwie i polityce. Przedmiotem artykułu jest prezentacja poglądów na temat wojny w polskiej myśli politycznej w latach 1815-1830. Kolejno zaprezentowano poglądy środowiska ugodowego, umiarkowanego i radykalnego. Uzupełnienie analizy stanowią wybrane narracje historyczne oraz uwagi przedstawicieli nauki.

Słowa kluczowe: wojna; Królestwo Polskie; myśl polityczna; wojny napoleońskie; powstanie listopadowe 